\title{
A nyelvtani nem hiányának következményei a magyar nyelvben
}

\section{2. rész"}

Elekfi László emlékének

6. A genusz meglétének, illetve hiányának hatása a mondatszerkesztésre. Az egyik leginkább meghatározó szófaji sajátosság a s zintag ma alkotás i k é p e s s é g. Az adnominális szerkezetekben szereplő lexémaosztályoknak már a lexéma szintű megjelenési formáját is jelentősen befolyásolja a nyelvtani nem kategóriájának megléte a nyelvben. Ezzel együtt jár az a követelmény, hogy rugalmasan igazodjanak a főnévi alaptag neméhez. Ebből a szempontból közömbös, hogy az adott nyelvben két- (francia), három- (latin), esetleg négyféle (orosz hímnemú élő és élettelen?) nemet különböztetnek meg; nem számít az sem, hogy a paradigmában mennyi a homonim alak, vagy hogy vannak „egyalakú" melléknevek is, mint például a latin vetus 'régi' és az - ns képzős participium imperfectum activi. A lényeg az, hogy ezekben a nyelvekben a $\mathrm{n}$ e me nként váltakozó alakú lexémákat szám, eset és nem szerint is mindigegy főnév aktuális ragozásának és a nemének is megfelelően kell beépíteni a mondatba - természetesen a saját paradigmájuk lehetőségei szerint.

Ezért aztán ha a természeténél fogva változékony alakú melléknév, melléknévi i genév vagy név más nem egy fönév determinánsa, hanem a mondatba igei állítmányként vagy igenévként beépített esemény - c s e le k vé s, történés vagy állapotváltozás - aktuális lefolyásának módját, illetve létezés, állapot minőségét jelöli, ki kell merevíteni, változtathatatlan alakú új szóvá: a dve rbiummá kell a lakítani a melléknevet, mégpedig vagy képzővel (pl. a latinban, oroszban, sőt még az angolban is), vagy a melléknévi végződések teljes elhagyásával (pl. a németben), de legalábbis a paradigma valamelyik alakjának egy bizonyos adverbiális jelentésben való rögzülésével (pl. lat. primum, multo).

Ezzel szemben a magyarban, mint láttuk, a melléknév (és a vele rokon számnevek, igenevek, névmások) vonzatként és szabad bővítményként is e funkciójuknak megfelelö saját esetalakjukban közvetlenül kapcsolódhatnak egy igei természetủ domináns taghoz is. Speciálisan (-a/-e előhangzós) melléknévi vagy számnévi (-szor, -szer, -ször) végződést is csak akkor kapnak, ha azt a meghatározói funkció jelentése kívánja - összhangban azzal, hogy a főnévnek is a jelentésétől függ, felveszi-e például a -kor időhatározói viszonyjelölőt.

*Az első részt 1. MNy. 2019: 409-421.

Magyar Nyelv 116. 2020: 19-31. DOI: 10.18349/MagyarNyelv.2020.1.19 
6.1. Egyeztetések az alany-állítmányi szókapcsolatban. Az indoeurópai nyelvek alapszabálya, hogy az állítmánynak egyeznie kell az alannyal nemben, számban, esetben és személyben. Láttuk, hogy ez nemcsak a névszói állítmánykiegészítőkkel alkotott szerkezetekre igaz, de az összetett igealakok kialakulásával az igei állítmányra is kihat.

Az, hogy a magyarban semmiféle genuszra nem kell tekintettel lenni, nem jelenti azt, hogy nem kellene egyeztetni személyben, számban és esetben is az állítmányként használható névszókat és névmásokat a mondat grammatikai alanyával. Közös esetük a - nálunk jelöletlen - nominatívusz, az alapvetően formai számbeli egyezés pedig értelemszerü: akár homogén, akár heterogén többségü az alany, a jelentéskörébe tartozó valamennyi egyedet egyformán minősítjük, tehát az állítmány az abszolút többség jelét kapja: A gyerek-ek / Pisti-ék / a fi-ai-nk ügyes-ek volt-ak - de: az egész csapat $\emptyset$ ügyes $\emptyset$ (volt $\emptyset$ ). A több birtok jele akkor kerülhet a szerkezet bármelyik tagjára, ha azt a „,birtokoltság” kifejezésének igénye megkívánja. A személybeli egyeztetésre azonban a névszók személyjelölő eszközei nem alkalmasak - annak ellenére, hogy ezek is a személyes névmások agglutinációjából keletkeztek, akárcsak az igei személyragjaink többsége. Csakhogy ezek soha nem a mondat grammatikai alanyának személyére utalnak, hanem arra, hogy az alapszó denotátuma összetartozik a valóság egy másik (valamelyik grammatikai személyként azonosított) elemével - ezt fejezi ki nyelvünk a birtokviszony grammatikai eszközeivel, akár szerepel a „birtokosi” lexéma a mondatban, akár nem. Ezért van szükség még kijelentő mód jelen időben is egy igei segédszóra, a k o pulára, hogy legyen, ami utal az alany személyére: éhes vagyok. A többséget a névszó maga is jelölni tudja, ezért ha nincs idö-, módvagy épp aspektusbeli többletjelentése az állítmánynak, a T/3. személyben sem kell kopula a predikatív szókapcsolathoz. A kijelentő mód jelen idejében az egyes szám harmadik személyủ igéink is a személyrag hiányával különböznek az alanyi ragozás többi paradigmatagjától, vele párhuzamosan a mi n y e lv ü n kbe n va lószínüleg mindig is legfeljebb zéró fokon jelent meg a kopula a névszói predikátumok mellett - és nem, ,elhagyható", mint a személyragozó latinban, nem is ,e $1 \mathrm{maradt} ”$, mint azt az alanynak vagy a személyére, vagy a nemére utaló orosz nyelvben láttuk.

A szintaktikai viszony azonossága és a legalább értelmi számegyeztetés a predikatív szintagmák egyenes leszármazottjának tekinthető é r t e $1 \mathrm{~m}$ e z ő s kap-

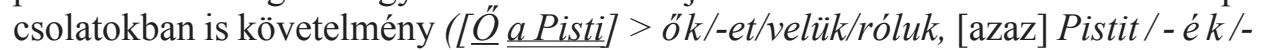
et/-kel/-röl, [vagyis] a másik c s a pat/-ot/-tal/-ról, [szóval] a tavalyi verseny gyöztes ei/-t/-vel/-röl stb.). - Az indoeurópai nyelvekben pedig a z értelmezö esetében sem lehet figyelmen kívül hagyni az értelmezett szó nemét.

6.2. A jelzős szerkezetek. Szembeötlőbb a különbség azoknak a szerkezeteknek a felépítésében, amelyek egy alárendelő viszonyú tömbként, mint egységes főnévi csoport (phrase) alkotják az állítmány egy-egy vonzatát, szabad bővítményét vagy magát a névszói állítmányt. Ezekben a determináló tagok az indoeurópai nyelvek szabályai szerint kötelesek követni a főnévi fej nemét, számát és esetét - nem győzzük hangsúlyozni: mindig a maguk sajátos ragozási lehetőségei 
szerint. Különleges szerepet kapnak az artikulusok, amelyekre a fönévi végződések kopásával egyidejüleg át is hárulhat a genuszjelölés feladata, és a morfológiai alakváltozatok gazdagsága a (gyakran jobbra bővítő) szórend fellazulását is eredményezheti. Ez leginkább a latinban figyelhető meg, s a klasszikus szerzőknek számos stilisztikai bravúrra adott alkalmat a szerkezettagok elszakítása, majd az azonos funkciójú végződések révén megvalósuló visszakapcsolás. Illusztrációul csak egyetlen versszakban figyeljük meg Horatiustól (Carm. 2, 12) a közbeékelésektől szétfeszített, mégis összeölelkező jelzős szókapcsolatok alakzatait, ahol az elkülönített melléknév hívja-vonzza-keresteti a fönévi alaptagját, különösen, ha elöl áll:

Nolis longa ferae bella Numantiae,

nec durum Hannibalem, nec Siculum mare

purpureum sanguine mollibus

aptari citharae modis

Devecseri Gábor fordításában:

Hirdetnem ne kivánd büszke Numantia

hosszas harcait és bösz Hannibált s a pún

vértől bíborosult tengeri torlatot

lágyabb zengzetủ lantomon

Az összekapcsolódó szerkezettagok jelölését így lehetne érzékeltetni:

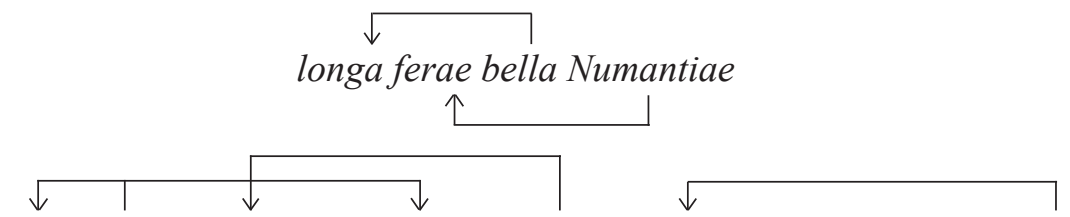

Siculum mare Poeno purpureum, sanguine, mollibus aptari citharae modis

A magyar melléknévnek nincs ilyen egyeztetési kényszere, ehelyett a mi szabad szórendúként számon tartott nyelvünkben a jel ző s s ze r k ez e teknek van a legszigorúbban szabályozott kötött s zórendje. Tudjuk, hogy ennek szabályai szerint a jelző mindig megelőzi a jelzett szót, közéjük semmiféle idegen elem nem ékelődhet be, s az is ismerős szabály, hogy ugyanazon főnévhez tartozó többféle jelzőből felépülő szerkezeten belül közvetlenül a főnév előtt áll a minőségjelző, azt előzi meg a mennyiségjelző. Mindezeket egységes keretbe foglalhatja a mutató névmási kijelölő jelző, amelyet kivételesen nekünk is egyeztetnünk kell szám és esetfunkció szerint a főnévvel, ha a főnév határozottá vált jelentését a névelö is megerösíti, összefogva és bizonyos mértékig lezárva a szerkezet szemantikailag szorosabban összetartozó részét. Csak ezek után, helyesebben ezek elött, a birtokszótól legtávolabb áll a birtokos jelző. Ez így sem látszik egyszerünek, és számos sajátos problémát is felvet. Kezdjük a végén.

A birtokos jelző az a mondatelemünk, amelyet az indoeurópai nyelvek vagy a genitívuszi esetalakkal fejeznek ki (pl. lat. vox p o p u li 'a nép szava', or. жизнь матери 'az anya élete') vagy egy viszonyszóval (ang. the pages of this book 'e könyv lapjai', fr. la maison de Paul 'Pál háza'), vagy a kettö kombinációjával (ógör. $\dot{\eta} \tau o \tilde{v} \pi \alpha \tau \rho$ ò $\varsigma$ oikía 'az apa háza') Nem is szokták 
a jelzők között tárgyalni, inkább mint jellemzően adnominális bővítményt, determinánst emlegetik, hiszen a genitívuszi esetnek valóban létezik adverbális használata is. Például a létigével álló kapcsolata megfelel a magyar -é birtokjeles állítmánynak: quae mulieris fuerunt, viri funt nomine dotis 'amik az asszony-é-i voltak, a férjé-é lesznek hozomány címén'; a gen. criminis is a 'vádol' jelentésủ ige vonzataként jelöli a bünt, a m i v e l vádolnak valakit. (A magyarok számára készült Görög nyelvtan pedig bizonyára a legtipikusabb használatnak megfelelö magyar birtokos jelzö terminus hatására magyarázza az ógörög genitívusz esetét fönévi jelzö-ként: MAYWALD-VAYER-MÉSZÁROS 1978 ${ }^{10}: 33$. )

A magyar birtokos szerkezet azonban nemcsak - az ösi OV szórendet követö sorrendjében tér el az indoeurópaitól, hanem jelölési módjával is: az, hogy a jelöletlen birtokosi fónév ahhoz a másik főnévi értékủ szóhoz tartozik meghatározó tagként, amelynek a birtokoltságát egy toldalék jelzi, csak akkor derülhet ki, ha beilleszkedik a szórendileg kötött jelzős szintagmába. Nem férkőzhet azonban be a mennyiségjelölő és minősítő determinánsok meg a birtokszó közé, mert azonnal magához rántaná, a saját jelzőivé tenné őket: a városnak (e (két (kis utcája))) $\neq$ (e (két (kis váro snak))) az utcája. Nagy kár, hogy ezt nem veszik figyelembe a rendezvényeik elnevezésekor azok a szervezők, akik - mondjuk - az 5. Fanyüvők Világtalálkozója eseményeire várják az érdeklődőket. (Nem tudom, az indoeurópai nyelvű meghívók szövegének képét is követni akaró tükörfordítás, vagy a tulajdonnév egységének rosszul értelmezett tisztelete eredményezi-e, engem elszomorít, hogy csak minden ötödik fanyűvő jöhet a rendezvényre. Vajon fognak nálunk egyszer Fanyüvők 6. Világtalálkozójá-t is rendezni?)

A birtokos-birtok szórendbe fellazulást hozott a birtokoson megjelenő datívuszi eredetü -nak, -nek rag. A részeshatározónak és a birtokosnak lényegében igencsak közeli rokon szemantikai tartalma nem újdonság, és nem is meglepö: ha valaki ne $k$ adunk valamit, akkor az illetö n e $k$ már lesz valami $j$ e, attól kezdve az a valami az övé lesz, vagyis az ö valamije lesz.

Hogy a „valaki” és a „valamije” között létrejövő tulajdonosi viszonyt melyik mondatszerkezettel fejezzük ki, az elsősorban annak a függvénye, hogy miről is szól a mondat. A jelzős kapcsolatban az elöl álló determináns - a birtokos - viszi el a szólamhangsúlyt, ez lesz nyomatékosabb, elvégre ez különbözteti meg a birtokot minden más a hasonló dologtól. A tulajdonképpeni té m a azonban a topic pozícióban levő teljes birtokos jelzős szerkezetnek a z a la p ta gj a, annak - az öszszes elébe halmozott determinánsával körülhatárolt - denotátumáról állítunk valami fontosat. (Pl. A rút kis kacsa tör tén e tét || legalább hússzor mesélte már.) Ha viszont a birtok az, amivel lényegében új információt tárunk a partnerünk elé, az erősebb hangsúllyal ejtett birtokszó a predikáció fókuszába kerül, és ilyenkor szünet előzi meg. Megváltozik a mondat aktuális tagolása: most már a birtokos a téma, róla állítunk valamit, például azt, hogy Egyik(nek\|a) pénze, másik(nak\|az) esze több. Ehhez élő beszédben talán még elég is volna a megváltozott intonáció, de a rag és a vele együtt belépő névelö rásegítenek a hangsúlyok eltolására, és inkább érezzük, hogy „kinek áll a rendelkezésére” ebből vagy abból nagyobb mennyiség. - Ettől azonban a mondat nyelvtani alanya még a pénze és az esze marad. 
Lehet elmélkedni azon, hogy a datívuszi rag belépésével a fenti példában továbbra is a birtokszóhoz tartozó j e $1 \mathrm{z}$ ő $\mathrm{m}$ a ra d t - e a birtokos, vagy már inkább az állítmány hat á ro z ój a . A topikalizált birtokos jelöltségének eredménye az lett, hogy ma mára birtokos jelző bármikor megjelenhet ragosan i s, igaz, nem mindig kötelezően. (A datívusznak a birtoklásmondatokban és birtokos szerkezetekben való megjelenését és szerepét történeti-tipológiai szempontból is behatóan tárgyalja HAVAS 2011: 203-222.) A raggal jelölt bir t o k o s aztán már a kommunikációs célnak megfelelően szabadabban mozoghat a mondatban, és nemcsak egy hosszabb szerkezet élén állva jelzi elöre saját függőségét, de hátra is vethető; a birtokosnak és az értelmezőjének az egyeztetését is jobban szolgálja, mint a jelöletlen alak, a többszörös birtokviszony is a ragos alak segítségével építhető fel egyértelmüen. - Az viszont jó lenne, ha az anyanyelvoktatás több figyelmet szentelne annak, hogy mikor hasznos a ragos birtokos jelző megjelenése, és mikor válhat akár értelemzavaróvá is az elmaradása. Mert annak a hangsúlyozása, hogy „túlterhelt” a -nak/-nek végződés, kerüljük el a „,sok csúnya ismétlődést", rengeteg rosszul szerkesztett mondathoz vezet. (M. KORCHMÁROS 2006: 58-59, 284-286.)

Jelzős szerkezeteinkben sok izgalmas kérdés merül fel a többi jelző sorrendjével, a jelzők hierarchiájával, tömbösödésével, a mutató névmási kijelölö jelző elhelyezkedésével, egyeztetendő és ragozhatatlan változatainak használatával kapcsolatban; ezek annyiban függnek össze a nyelvtani nem hiányával, hogy a genuszos egyezést helyettesíti a szórendi kötöttség. Mivel pedig e szerkezetek csakis balra bővíthetök, mindig a fej kimondása elött kell elhangzania nemcsak az összes jelzőnek, de mindazoknak a bővítményeknek, viszonyszóknak is, amelyeket például egy melléknévi igenévi jelző vonz. Egy-egy bonyolultabb, sok adatot tartalmazó tudományos vagy jogi szövegben ez nemcsak a befogadó félnek jelenthet kihívást, de a megalkotása vagy épp idegen nyelvre fordítása is komoly feladat, sok buktatót rejthet. És akkor még nem beszéltünk a szinkrontolmácsok gondjairól.

A nem szerint is egyeztetett jelzőkre azonban olyan feladatok is hárulnak, amelyeket a mi nyelvünk egészen másképp old meg. Szórendi variálhatóságuk révén ugyanis változhat a funkciójuk. Például az ógörögben egyaránt jelzős szer-

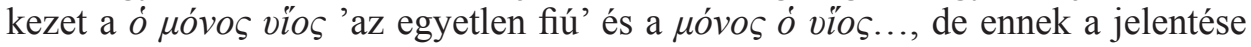
magyarul már 'egyedül a fiú...'; A latin in summo monte 'a hegy tetején', míg az in monte summo jelentheti a $\mathrm{zt}$ is, hogy 'a legmagasabb hegyen'. TÖTTÖSSY (1977: 223) erről így fogalmaz: „nem a melléknév a jelző a főnév mellett, hanem fónév a jelző a melléknév mellett".

6.3. Kettős szerkezetek: az állítmány kiegészítői. A szerkezeteket összetartó erő ugyanis soha nem az egyeztetéssel kezdődik, és homonim alakok esetében nem is azon múlik, hanem az elemek jelentésén. A Forrón szeretem a teát mondat a ,a tea legyen forró” igényemet fejezi ki; a Forrón szeretem Annát mondatok esetén senki sem gondol arra, Annának be kellene lázasodnia ahhoz, hogy szerethető legyen, világos, hogy az érzelmek hőfokát jelöli a ragos melléknév. A magyar mondatoknak a grammatikai struktúrája sem különbözik lényegesen: 
mindkét mondatban szabad határozói bővítményként az igei állítmánnyal alkot alárendelő szintagmát a melléknév:
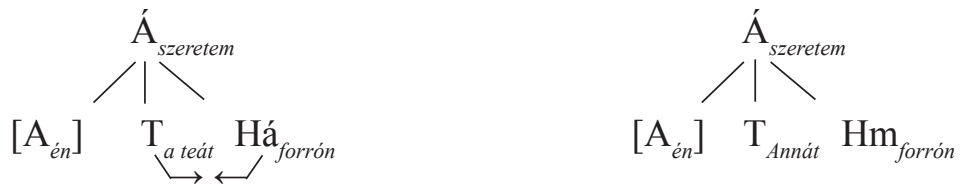

Azt, hogy forró minőség mikor jellemzi a tárgy állapotát, és mikor minősíti a mértékét az alany azon affektív állapotának, amelyet az igei állítmány fejez ki, kizárólag a szemantika alapján dönthetjük el.

Más a helyzet a nemek kifejezésének igényére (is) épült indoeurópai mondatszerkezetben. Ott választani kell, hogy a melléknévböl képzett adverbium vagy az egyik főnévi értékü alakkal egyeztetett melléknév lesz-e a helyes. ${ }^{1} \mathrm{Az}$ indoeurópai nyelvek mondataiban az állapothordozóval e setben, számban és nemben is egyeztetendö állapotjelölő az állítmánynak a kiegészítője lesz, létrejönnek a kettős alany, kettős tárgy, esetenként kettős datívusz szerkezetek, amelyekben a melléknévi természetüek neve attributum praedicativum, a fónévvel kifejezetteké appos itio prae di cativa. (Lat. nemo nascitur dives [Sen. Epist. 20,13] 'senki sem születik gazdagnak'.)

Nekünk négy olyan igénk van, amelynek alakjait a csak igei természetü tövön kifejezhető grammatikai viszonyok jelölése érdekében kopulaként használhatjuk (idő és mód: volt, lesz, volna, lenne, lett volna; aspektus [!]: marad, múlik; alanyszemély kifejezése, illetve egyeztetése: vagyok, vagy, vagyunk, vagytok). Ilyenkor - csakis ilyenkor - állhat mellettük két nominatívusz, amelyből az egyik a tulajdonképpeni névszói állítmány, a másik az alany. Sem két „valódi” tárgy, sem kétféle, azonos alakú vonzat nem szerepelhet az egy állítmányra épülő mondategység struktúrájában. Bármennyire alkalmas is alanynak vagy tárgynak valami, egy minősítési vagy átalakulási folyamat különböző fázisai közül csak az egyikben szerepelhet alanyként, vagy tranzitív ige mellett tárgyként. A másiknak változnia kell, mégpedig h a tár o z ó i formára: a vér nem válikvíz zé, tehát $a$ vérböl sohasem lesz viz; kenhetem a vajat a kenyérre, meg vajjal is a kenyeret, de választanom kell. (ZSILKA 1966; H. MOLNÁR 1969.) ${ }^{2}$

${ }^{1}$ Az idegen nyelvet oktató tanárok a megmondhatói, milyen nehezen veszik be a magyar diákok, hogy a melléknevet itt határozóval fordítjuk. Mert a melléknevet grammatikai formája látványosan a főnév szerkezetéhez kapcsolja, és a kezdő nyelvtanulónak még nincs meg az idegen szöveg értéséhez elegendő kompetenciája, még magyarul gondolkodik, de sajnos keveset tud magyar anyanyelvéröl.

${ }^{2}$ Ez természetesen nem zárja ki halmozott mondatrészek mellérendelő szószerkezeteit. Az a főnévi igenévvel épülő szerkezettípus viszont, amit a magyarban nevezett kettős alanynak, illetve kettős tárgynak a hagyományos nyelvleírás (MMNyR. 2: 78, 115-116, 151-152), csak felületesen nézve tartalmaz tárgyat vagy alanyt, a mi esetvégződés felvételére képtelen infinitívuszunk valójában az állapothatározó kérdéseire felel, állapothatározói mellékmondatokkal egyenértékủ. (Vö. M. KORCHMÁROS 1980-1981, 1984.) 
Az indoeurópai nyelvekben azonban ott is öröklődött az állítmányt kiegészítő alany és tárgy, ahol az esetalakok nem különböznek, és persze a váltakozó nemü szavaknál megint egyeztetni kell a nemet is. Ugyanezen az elven épül fel a német Gleichsetzungsnominativ, illetve Gleichsetzungsakkusativ (pl. Er nennt den Streit ein Misverständnis; SCHUMACHER Hrsg. 1986: 25) és az angol nyelv számos intranzitív, illetőleg tranzitív link verb-jével járó subjectiv és objectiv complement (vö. SINCLAIR et al. 1992: 172-177).

6.4. A nyelvtani nem hatása az igeneves szerkezetekre. Az összetett igei és igenévi paradigmatagokban is fontos szerepet játszó particípium melléknévi ragozása az ún. igeneves szerkezetekben eredményezi a leginkább szembetünő különbséget.

A magyarban az „egyszerü” mondatok „mondatrövidítő” melléknévi igenevei mindig egy olyan jelzői mellékmondattá bonthatók fel, amelynek az igei állítmányát építettük be általuk annak a fömondatbeli főnévnek a jelzőjéül, amely antecedense volna a mellékmondat alanyának (a labdát rúgó fi ú ' a z a fiú, aki rúgja a labdát') vagy tárgyának (az elrúgott labda 'az a $1 \mathrm{abda}$, a melyet vki elrúgott'; a bizonyitandó tétel' a z a téte l, a melyet bizonyítanánk' stb.).

A latinban nemcsak jelzői, de határozói mellékmondatok is transzformálhatók (rövidíthetők) a jelzőként egyeztetett melléknévi igenevekkel, mégpedig nemcsak állapothatározói mellékmondatok, hanem idő-, mód-, ok- és célhatározóiak is. Sőt, megengedő vagy feltételes értelem is járulhat az igenévhez, amelyet alaki tulajdonságai alapján nevez partic ip ium coniunctum-nak a nyelvtan, ha aza mondat valamelyik fönévi eleméhez egyezte tés sel kapcsolódik. Pl. Caesar veritus, ne noctu ... profugerent..., iussit... (Caes. B. G. 1, 20,1) 'Caesar [at tó1] félve, hogy éjjel megszöknek, parancsot adott, ...'; szó szerint: 'a félő Caesar', ami elég furcsa jellemzés volna.

Ez a szerkesztési mód természetesen érvényes marad további beágyazások, tehát a nominativus cum infinitivó-val és az accusativus cum infinitivó-val történő mondatalkotás során is: erre ismét Horatiustól nézzünk meg egy példát (Carm 3,30 10-14): Dicar [ e go ], ... ex humili po te $n s$, princeps Aeolium carmen ad Italos deduxisse modos. Az alanyt, melyre viszszakapcsol a (történetesen egyvégződésü) két nominatívusz, a passzív igerag mutatja. Magyarul csak személytelen tárgyas ragozással és határozói körülírásokkal adható vissza a pontos értelme: 'El fogják mondani róla m, hogy kicsinyből [válva] hatalmassá, fejedelemként vezéreltem át az aeol dalt itáliai mértékre'; vagy: 'Úgy fognak emlegetni [e ngem ], mint aki kicsinyböl [lett] hatalmassá, [és/mert?] feje de le mként vezéreltem át ....' (A metafora értelme: princeps volt a titulusa a szenátusban az ifjú Octavianusnak, aki légióit vezérelve hozta el Rómának az aranykort.)

Érthető módon befolyásolja a nyelvtani nem magának a főnévi igenévnek a használatát is, hiszen az infinitivus perfectus is összetett: a participium perfectum passivi és a létigei infinitivus együtteséből áll, így mind a nominativus cum infitivo, mind az accusativus cum infinitivo esetében igazodnia kell egy fönévi vagy névmási alanyhoz, illetve tárgyhoz. 
A mi szemszögünkből nézve a latin melléknévi igenév egyenesen a feje tetejére állíthatja a valóságot, ezt leginkább azok a példák bizonyítják, amikor az igenévnek a jó magyar fordításban szabályosan az igéből többnyire -ás/-és képzővel alkotott főnév felel meg. Mint az időmeghatározás közismert formulája, amely az eltelt időt post urbem conditam 'a város megalapítása után' méri, holott szó szerint lefordítva magyarul így lenne: a megalapitott város u tán. A latin szerkezetnek más a logikája: a conditus, -a, -um csak az alapítást elszenvedő létesítményhez igazodva jelenhet meg: mivel a 'város' = urbs, -is, $f$, a condita alakot kell választani, aztán a z e gé s z s z er k e ze te t a prepozíció által megkívánt akkuzatívusz esetüvé kell alakítani: ez a 3. deklinációban ragozott főnév mellett az igenév 1. deklináció szerinti formájával válik tökéletessé. - A magyar szerkezet az esemény idejéhez viszonyít a főnevesített határozóval, s az esemény érintettje a szintagmában az alárendelt birtokos jelzői tag, a latinban az eseményt jelölő melléknévi igenév a jelző, alakjának megválasztása pedig az esemény patiensét megnevező szótól függ.

Ezt a számunkra fordított logikát követik az ablativus absolutus néven számon tartott particípiumos szerkezetek is, amelyek onnan kapták nevüket, hogy a főnév, amelyhez a melléknévi igenév igazodik - $\mathrm{s}$ amely a ragozott igével megszerkeszthető határozói mellékmondat cselekvő vagy szenvedő alanya volna -, nem azonosítható a feltételezett fömondat egyik elemével sem, s így a participum is független a többi mondatrésztől. Genusz szerint váltakozó melléknévi természeténél fogva azonban (még az egyalakú participium imperfectum activi is) képtelen elszakadni cselekvéshordozójától, tehát a magával hozott saját alanyához igazodik nemben és számban. Mivel pedig a kifejezendő határozók jelentése az ablativus esetet kívánná meg, az egész jelzős szintagma abba kerül. A megfelelö magyar mondatokban legtöbbször határozói igenevet, határozói mellékmondatot, vagy itt is igéből képzett fónevet alkalmazunk határozóként, melynek a birtokosi determinánsa lesz a latin jelzős szerkezet alaptagját képező főnév megfelelöje. Galba nullo hos te prohibente ... legionem in Allobroges perduxit (Caes. B. G. 3, 6, 5) 'Galba ú g y vezette át legióját az allobroxokhoz, hogy semmiféle ellenség nem akadályozta' vagy: 'Galba semmiféle ellenségtől nem akadályozva vezette...', esetleg '...bármilyen v. mindenféle ellenség akadályozása nélkül...'. (A szerkezet magyarra fordítását a totális tagadás visszaadása is nehezíti.)

Hasonló elv szerint épülnek fel a gerundívumos szerkezetek is. Gerundivum-nak azt a melléknévi igenevet nevezték, amelyet - a gerundium elnevezésű fónévi igenévhez hasonlóan - az imperfectum tőből képeztek, és a tranzitív igék szenvedő jelentésü participium imperfectumának felelt meg. Célhatározói értelemben került a mondatba, valószínúleg ezért kezdi felvenni a kései latinban, kb. a 3. századtól az instans actio jelentését. (Vö. TöTTÖSSY 1969.) Pl. locus ad castra pon enda idomeus 'táborverésre alkalmas hely', szó szerint szintén: 'a felverendő táborhoz alkalmas hely'.

Természetes, hogy mivel a létigének ekkor még nincsenek meg a participiumai, az ablativus absolutus szerkezete is enélkül, csonkán épül fel, ha az általa rövidített határozói mellékmondat állítmánya névszó + létige volna: ez az a b la - 
tivus absolutus mancus: Natura duc e errari nullo pacto potest (Cic. Leg. 1, 20.) 'Semmiképp se lehet tévedni, ha a természet a vezető [nk]'. A beágyazott latin mellékmondat kifejtve si natura dux est volna.

$\mathrm{Az}$ ógörögben nincs ablatívusz eset, de van melléknévi módon egyeztetendő igenév a jelzői és határozói szerepkörökben, és van független particípiumos szerkezet is, csak éppen a genitivus absolutus fejezi ki az idő-, ok- vagy állapothatározói mellékmondatokat igeneves szerkezetbe tömörítő formát. A független particípiumos szerkezettípus igen ösi örökség az indoeurópai nyelvekben, a szanszkritban locativus absolutus és genitivus absolutus alakban élt. (L. TÖTTÖSSY 1977.)

És öröklődött is. PAOLO DRIUSSI szíves közléséből tudom, hogy a mai olasz nyelvtanok is számon tartják a participii passati assoluti szerkezettípust. Ebben az előidejủ igenévnek - amely tárgyas igéből képezve szükségképpen szenvedővé válik - a saját alanya különbözik a fömondatétól. Természetes a feltételezés a mai beszélők számára, hogy ez a latin szerkezet folytatása, mint ahogy azok a fónévi és melléknévi szerkezetek is az ablativus absolutus mancus leszármazottai, amelyek ,közel állnak a parti c i pi u m a b s olu tu mhoz”, pl. contento te 'lévén te boldog', azaz 'ha/amikor/mert te boldog vagy', lui presente 'lévén ő jelen', tehát 'az ő jelenlétében'. (Vö. SERIANNI 1989²: 482.)

\section{A genusz hiányának hatása a nyelvi rendszerre. Összegzés és kite-} kintés. Láttuk, hogy a nyelvtani nem - ott, ahol van - a fónévnek és a fónévi névmásnak is „vele született” jellemző tulajdonsága, alapvető kategóriája. Kimutattuk, hogy nem csak a megléte, de a hiánya is rányomja bélye gét a zon lexématípusok szófaji minőségére, amelyek szintagmatikus kapcsolatokat alkotnak a fónevekkel; azt is láttuk, hogy a z e miat t eltérö szófaji természetek más és más típusú szintagmák megszerkesztését teszik lehetővé a genuszos és a nyelvtani nemet nem ismerő nyelveken beszélők számára. Rámutattunk, hogy az így kialakult mo n d a ts z e r k e z e t e k igen tartósak, és még akkor is megmaradnak a nyelvben, ha annak egyéni fejlődése következtében a névszók már alig vagy egyáltalán nem mutatnak nembeli vagy ragozásbeli eltéréseket.

Magától értetődik, hogy a nyelvtani nem kategóriájának meglétén vagy hiányán kívül még rengeteg belső törvényszerüség és külső befolyás hat egy-egy nyelv történeti változásaira. A szókincs állandó változásán kívül elég csak a történetileg oly sokat változó fonémákra, az OV vs. VO alapszórend különbségéből adódó eltérésekre, a szó elejére eső hangsúllyal szemben a „paenultima - antepaenultima” hangsúlyozással is összefüggő szóalakváltozási tendenciákra, az agglutinálódás és a flektálás szerepére a ragozási paradigmák alakulásában, a névelők meglétére, illetve hiányára, a megjelenésükkel rájuk átháruló sokféle funkcióra utalni. A jelen dolgozatban csupán azt kívántuk bemutatni, hogy a nyelvtani nem hiánya is hozzájárult ahhoz, hogy a mi nyelvünk más megoldá s o kra kén y s z e r ült ott, ahol a genusszal élö nyelvek számára a szavakat egymáshoz füző nyelvtani viszonyok kifejezésére a nemre (is) utaló egyeztetések kínáltak lehetőséget. Ez alakította másképp a mi mellékn évi használatú 
szavaink a lakját, ragozását, ezáltal hatott határozószavaink osztályának alakulására is. Befolyásolta ig e né vre nds ze r ünk mai állapotát, és hozzájárult ahhoz, hogy igeneveinket nem az igei paradigma részeként, hanem egységesebben és önállóan, átmeneti szófajcsoportként kezeljük. Genusztól független, szemantikai gyökerekből táplálkozó közös né v s z ó ra g o z á s un k kiterjesztette az adverbális szintagmák lehetőségeit, átre nd e z ve a mondataink szerkezetét. A kettős szerkezetek állítmánykiegészítő alanyai, tárgyai, sőt olykor egyéb mondatrészei helyett nekünk más a ha tá ro zórendszerünk; adnominális szerkezeteinkben az egyeztetési kötelezettség helyébe a s zó r e ndjü k k ötötts é ge lépett, amibe bekapcsolódott a birtokosi determináns is, ezzel megszületett a birtok os je l ző .

A mondataink grammatikai struktúráját a lexémaállomány szintagmaalkotási lehetőségei szabják meg. Ezek pedig a magyarban azt eredményezték, hogy az igein kívül van névszói állítmányunk is, aminek csak paradigmaalkotó változatai a (mindössze 4) kopulával kiegészített összetett állítmányok. „Subiectum est praedicatum” típusú ítéleteink szerkezetének nem rés ze az ige, ha a praedicatum biztosítani képes az igei állítmánytól is elvárt (és azon is zéró fokú, tehát testes eszközzel nem képviselt) minimális grammatikai feltételeket: szolgáljon információval az időről, a módról, az alany számáról és személyéröl ( $\underline{\text { Jancsi }}$ is $\underline{\underline{o ̈ u ̈ l}}$, ha Julcsa boldog). Ennek megfelelöen a $\mathrm{m}$ a g y a r mondatnak nem az ige a grammatikai központja, hanem a z állítmány. Köréje szerveződnek az általa kötelezően vonzott vagy csak lehetségessé tett mondatrészek: a mondat nominatívuszi alanya, a tranzitív ige akkuzatívuszi tárgya és az összes többi: a határozók; a mondat valamennyi elemét morfológiailag meghatározott is m ert e tőj e g y e k kel kell ellátni. Nincs indirekt tárgy, nincsenek alanyi és tárgyi, sőt genitívuszi, datívuszi ,kiegészítők”, nincsenek külön adverbiumok é s prepozíciós (vagyis segédszóval és/vagy esetalakkal viszonyított) főnévi csoportok: mi mindezek szerepében valamilyen határozót szerkesztünk a mondatainkba. Külön mondattani kategóriát képeznek a je lzőin k, amelyek (az esetenként ragos birtokos és a névelőtől követett főnévi mutató névmás kivételével) mindig jelöletlenek, és mindig egy főnévi taghoz kapcsolódva kerülhetnek a mondatba. Tehát $n$ e $m$ a z ál1ít mány bővítmén y e i, bár kapcsolódhatnak az állítmányhoz is, ha az történetesen főnév. A jelző tehát ugyanúgy nem azonosítható a melléknévvel, mint az állítmány sem az igével, az adverbium a határozóval. Nem lehet egy kalap alá venni névelőt és birtokos névmást, mint az angol determinánsok osztályában, a mi nyelvünkben éle s e n e $1 \mathrm{k}$ ülön ül a más-más síkon mozgó szófaji-morfológiai elemzés és a mondaté. És nem tud értelmes magyar mondatokat alkotni, aki nem ismeri az utolsó ragig a mi morfológiánkat. (Aki nem hiszi, próbálja egyszer a fordítógombbal magyarítani a - mondjuk hollandul kapott Wikipedia-szöveget.) Ezért is nehéz a magyar nyelv.

A mondat nyelvtani szerkezetének elemeiből azonban még csak a szavak morfológiai tulajdonságain és a szintagmák felépítésén alapuló struktúrát alkotjuk meg. Más kérdés, hogy ezeket az elemeket hogyan rendezzük el aktuálisan. (Az indoeurópai nyelvekben 
a ragozott formák kopásával egyre inkább a szórendre hárult a sokszor alakilag meg sem különböztethető mondatbeli funkció jelölése. Ez és az ige kötelező jelenléte a predikatív szerkezetekben szinte kínálta a felületes elemző számára a logikai ítélet felöli közelítést a mondathoz is. Az ilyen elemzés azonban csak a „gyógymondatokban” működik. A grammatika a kötött szórendű nyelvekben sem azonos a logikával, $\mathrm{s}$ a mondatok aktuális tagolása ott is sok kérdést vetett fel (de ez nem a nyelvtani nemmel függ össze). A Mit állítok? és Miröl állitom? logikai ítéletalkotással két részre osztható mondatkonstrukció nálunk is érvényes, de a legritkább esetben felel meg a grammatikai állítmánynak és alanynak, mert a morfológia szabályaitól függően szerkesztjük, de az aktuális beszédhelyzetnek megfelelő sorrendben ágyazzuk be a kontextusba az egyes megnyilatkozásrészeket. Ráadásul az a téma, amiről valami újat mondunk a fókuszt tartalmazó rémával, a mi mondataink jelentôs hányadában bele sem kerül a konstrukcióba, mert - már úgyis ismert lévén - felszínen van a tudatunkban, legfeljebb az alanyi vagy tárgyas igealak, esetleg a határozói vonzatot reprezentáló igekötő utal rá. Vagy éppen arra szögezték az eligazító táblát, hogy ti. E mögött az ajtó mögött a ,, Titkárság” van.

Nyelvtanoktatásunk sürgető feladata volna a különféle elemzések terminológiájának következetes szétválasztása, a pontatlan definíciók korrigálása, a fogalmak tisztázása. Nyelvleírásunk során már BRASSAI SÁMUEL (részletesen pl. BRASSAI 1885) felismerte ezt, de csak az utóbbi bő fél évszázadban kapott egyre több figyelmet az aktuális tagolás, különösen ELEKFI LÁsZLÓ és É. KISS KATALIN munkássága révén. De a mai napig sincs mindenre kiterjedő, kielégítően definiált, általánosan elfogadott, a z is kolákban is tanítható, stabilan megkülönböztetett terminológiánk, amely ne zavarná össze a tanuló formálódó fogalmait a szemantikai agens, a grammatikai alany, a nominatívuszi alak, a mondat témája és a logikai szubjektum körül.

Kulcsszók: nyelvtani nem, szintagmaalkotás, egyeztetés, határozók, jelzői szórend, birtokos jelző, igeneves szerkezetek.

\section{Hivatkozott irodalom}

BENSELER 1931 ${ }^{15}$. Griechisch-Deutsches Wörterbuch. Teubner, Leipzig.

BERRÁR JolÁN 1977. Alany és állítmány. In: RÁCZ ENDRE - SZATHMÁRI IsTVÁN szerk.,

Tanulmányok a mai magyar nyelv mondattana köréböl. Tankönyvkiadó, Budapest. 79-93.

BRASSAI SÁmUEL 1885. A mondat dualismusa. Értekezések a Nyelv- és Széptudományok köréből XII. kötet 10. szám. Magyar Tudományos Akadémia, Budapest.

BUDENZ JózSEF 1881. A grammatikai genus hiányában. Nyelvtudományi Közlemények 16: $323-324$.

ELEKFI LÁSZLó 1957. A logika állítmány-fogalma és az állítmányi névszó. A Magyar Tudományos Akadémia Nyelv- és Irodalomtudományi Osztályának Közleményei 11: $145-146$.

ELEKFI LÁsZLó 1964. Az aktuális mondattagolás egyik alapformája a magyarban. Nyelvtudományi Közlemények 66: 331-370. 
ELEKFI LÁSZLÓ 1966. A predikatív viszony. Magyar Nyelvőr 90: 62-75.

ELEKFI LÁSZLÓ 1986. Petőfi verseinek mondattani és formai felépitése. (Különös tekintettel az aktuális mondattagolásra). Nyelvészeti Tanulmányok 27. Akadémiai Kiadó, Budapest.

ELEKFI LÁSZLÓ 1994. Magyar ragozási szótár. Dictionary of Hungarian inflections. Ford. KONTRA MiKLÓs. MTA Nyelvtudományi Intézet, Budapest.

É. KISS KATALIN 1992. Mondattan. In: KIEFER FERENC szerk., Strukturális magyar nyelvtan 1. Akadémiai Kiadó, Budapest. 74-160.

FODOR ISTVÁN 1958-1959. A nyelvtani nem kialakulása I-II. Nyelvtudományi Közlemények 60: 339-368, 61: 29-43.

HAVAS FERENC 2011. A prenominativitás. Elmélet és alkalmazása az uráli nyelvekre. Akadémiai doktori értekezés. Budapest.

KÁLMÁN LÁSZLÓ 2013. Az olvasónők és a nyelvésznők dilemmája. Nyelv és Tudomány 2013. 01. 14. https://www.nyest.hu/hirek/az-olvasonok-es-a-nyelvesznok-dilemmaja

Kiss ANGELIKA 2014. Szexistává tesznek-e a nyelvtani nemek? Nyelv és Tudomány 2014. 11. 06. https://www.nyest.hu/hirek/szexistava-tesznek-e-a-nyelvtani-nemek

M. KorCHMÁROS VALÉRIA 1980-1981. A „kettős alany” megítéléséről. Néprajz és Nyelvtudomány 24-25: 179-194.

M. KorchmÁros VAlÉRIA 1984. The Problems of „Double Object”. Nyelvtudományi Közlemények 86: 374-379.

M. KORCHMÁROS VALÉRIA 2006. Magyar nyelvtan nemcsak magyaroknak. Lépésenként magyarul. Magyar nyelvtani kézikönyv. SZTE Hungarológiai Központ, Szeged.

M. KorchmÁros VALÉria 2018. Mit állítok? In: BALÁZS GÉZA - LENGYEL KLÁRA szerk., Grammatika és oktatás - Időszerü kérdések. Struktúra, funkció, szemiotika, hálózat. ELTE BTK Mai Magyar Nyelvi Tanszék - Inter (IKU) - Magyar Szemiotikai Társaság, Budapest.

LEumann, MANu - Hofmann, J. B. - SzAnTyr, ANTON 1965. Lateinische Grammatik. 2. Bd. Syntax und Stilistik. Verlag C. H. Beck, München.

MAYWALD JÓZSEF - VAYER LAJOS - MÉSZÁROS EDE $1978^{10}$. Görög nyelvtan. Tankönyvkiadó, Budapest.

MMNyR. = A mai magyar nyelv rendszere. Leíró nyelvtan 1-2. Szerk. TOMPA JÓzSEF. Akadémiai Kiadó, Budapest, 1961-1962.

H. MolnÁR IlONA 1969. Az igei csoport, különös tekintettel a vonzatokra. Általános Nyelvészeti Tanulmányok 6: 229-270.

MORAVCSIK, EDITH 1972. On case markers and complementizers. Working Papers on Language Universals 8: 151-152.

ÖRSI TIBOR 2011. A nyelvtani nem választása szókölcsönzéskor. http://www.kodolanyi. hu/manye/2011_szombathely/kotet/10_orsi.pdf (2019. 10. 31.)

PAPP FERENC 1975. A magyar fónév paradigmatikus rendszere. Akadémiai Kiadó, Budapest.

PÉLI PÉTER 2009. A nyelvtani nem mint politikai „nem”. Nyelv és Tudomány 2009. 08. 11. https://www.nyest.hu/hirek/a-nyelvtani-nem-mint-politikai-nem

P. MAYER ERIKA - TÖTTÖSSY CSABA 1960. Latin mondattan és stilisztika. Kézirat. Változatlan utánnyomás. Felsőoktatási Jegyzetellátó Vállalat, Budapest. 
SCHUMACHER, Helmut Hrsg. 1986. Verben im Feldern. Walter de Gruyter, Berlin - New York.

SERIANNI, LUCA 1989². Grammatica italiana. Italiano comune e lingua letteraria. Suoni, forme, costrutti, in collaborazione con ALBERTO CASTELVECCHI. Utet, Torino.

SINCLAIR, JOHN et al. 1992. English Grammar. Collins Cobuild, London.

STANITZ KÁROLY 1987. Adalékok a nyelvtani nem természetrajzához. Doktori értekezés. József Attila Tudományegyetem, Szeged.

H. TÓTH IMRE 2011. Rövid összehasonlitó szláv nyelvtan. I. rész. Hangtan, alaktan (fönév, ige). Szöveggyüjtemény. 2., javított kiadás. JATEPress, Szeged.

TöтTÖSSY CSABA 1969. A latin gerundivum. Antik Tanulmányok 16: 205-208.

TÖTTÖSSY CSABA 1975. A görög és latin infinitivus-os szerkezetek. Antik Tanulmányok 22: 13-19.

TÖTTÖSSY CSABA 1977. A latin, görög és szanszkrit participiumos szerkezetek. Antik Tanulmányok 24: 221-224.

H. VARGA MÁRTA 2016. A „nem” (sexus, genus) fogalma. Nyelvtudományi Közlemények 112: 299-322.

VASVÁRI, LOUISE O. 2014. Problémás nyelvi nem a nem nélküli magyar nyelvben. TNTeF 4.1: 130-166. tntefjournal.hu/vol4/iss1/vasvari.pdf

ZSILKA JÁNOS 1966. A magyar mondatformák rendszere és az esetrendszer. (Tárgyas mondatszerkezetek.) Nyelvtudományi Értekezések 53. Akadémiai Kiadó, Budapest.

\section{The results of the absence of gender in the Hungarian language}

This paper offers a brief survey of the presence of gender distinctions in the parts of speech of Indo-European languages, pointing out the fact that the absence of gender has changed the grammatical forms not only of the Hungarian pronouns but of all of the words connected to a noun in a nominal phrase. The syntagmatic structures based on grammatical agreement by gender influenced not only the moods of determination but also the predicative structure, causing the system of "double" constructions with the predicative attributes and appositions. Instead of these there are a lot of adverbal forms in Hungarian, but a sentence construction can have only one "subject" and one "object", and Hungarian also has predicative syntagms with zero copula. While the order of these parts of the sentence depends on the functional sentence perspective (where all parts of the construction may be represented by the grammatical form of the predicate instead of pronouns), the word order of the adnominal constructions is strictly defined/fixed.

Keywords: gender, grammatical agreement, syntagmatic structures, copula, nominal phrases, adverbial structures, word order.

M. KORCHMÁROS VALÉRIA Szegedi Tudományegyetem 